\title{
Association Between Imaging Findings of Airway Obstruction Adjacent to Lung Tumors and the Onset of Interstitial Lung Disease After Nivolumab
}

\author{
KENJI NAKAHAMA ${ }^{1}$, AKIHIRO TAMIYA $^{1}$, SHUN-ICHI ISA $^{2}$, YOSHIHIKO TANIGUCHI ${ }^{1}$, \\ TAKAYUKI SHIROYAMA ${ }^{3}$, HIDEKAZU SUZUKI ${ }^{3}$, TAKAKO INOUE ${ }^{4}$, MOTOHIRO TAMIYA $^{4}$, \\ TOMONORI HIRASHIMA ${ }^{3}$, FUMIO IMAMURA ${ }^{4}$ and SHINJI ATAGI ${ }^{2}$ \\ Departments of ${ }^{1}$ Internal Medicine, and ${ }^{2}$ Thoracic Oncology, \\ National Hospital Organization Kinki-chuo Chest Medical Center, Osaka, Japan; \\ ${ }^{3}$ Department of Thoracic Malignancy, Osaka Prefectural Medical Center \\ for Respiratory and Allergic Diseases, Osaka, Japan; \\ ${ }^{4}$ Department of Thoracic Oncology, Osaka International Cancer Institute, Osaka, Japan
}

\begin{abstract}
Background: Compared to conventional cytotoxic chemotherapy, immune checkpoint inhibitors have shown a significant efficacy in the treatment of lung cancer. Although interstitial lung disease (ILD) is an important adverse event in immunotherapy, risk factors for ILD remain unclear. Patients and Methods: In this multicenter cohort study (UMIN000025908), 201 patients who were treated with nivolumab were retrospectively reviewed. Associations between the incidence of ILD and patient characteristics were evaluated. ILD grade and progression-free survival were analyzed according to the presence or absence of imaging findings of airway obstruction adjacent to lung tumors (IAOT). Results: In the multivariate analysis, the odds ratio (OR) of ILD for patients with a history of radiation pneumonitis or IAOT was $3.96(p=0.012)$ and $6.59(p=0.004)$, respectively. ILD occurred in six (37.5\%) out of 16 patients with IAOT and $19(10.3 \%)$ out of 185 patients without IAOT. Three out of the six patients with ILD and IAOT had ILD of grade 4 or more. The median progression-free survival of patients with and without IAOT was 0.9 and 3.2 months, respectively $(p<0.001)$. Conclusion: IAOT was strongly associated with the occurrence of ILD after therapy with nivolumab.
\end{abstract}

This article is freely accessible online.

Correspondence to: Kenji Nakahama, MD, Department of Internal Medicine, National Hospital Organization Kinki-chuo Chest Medical Center, 1180 Nagasone-cho, Kita-ku, Sakai City, Osaka 591-8555, Japan. Tel: +81 722523021, Fax: +81 722523041, e-mail: nakahama_kenji@outlook.jp

Key Words: Airway obstruction, interstitial lung disease, lung cancer, nivolumab, risk factor.
Compared to conventional cytotoxic chemotherapy, immune checkpoint inhibitors (ICIs) have shown a significant efficacy in the treatment of lung cancer (1-6). Nivolumab is an ICI that binds to programmed cell death-1 (PD1) on activated immune cells to disrupt its interaction with programmed death ligand-1 (PD-L1) and-2. When administering ICIs, such as nivolumab, unique adverse events known as immune-related adverse events are often problematic. Interstitial lung disease (ILD) is a particularly important immune-related adverse event. Previous studies have reported that the incidence of nivolumab-related deaths due to ILD was higher in patients with non-small cell lung cancer than in patients with other malignancies (e.g. melanoma) (7, 8). This suggests that the lung microenvironment may be a crucial factor in inducing ILD. In this study, we analyzed clinical data to clarify the risk of ILD focusing on factors that may affect the lung microenvironment.

\section{Patients and Methods}

Study design. A retrospective multicenter cohort study was conducted on 201 patients with advanced or recurrent non-small cell lung cancer who had previously been treated with nivolumab $(3.0 \mathrm{mg} / \mathrm{kg}$ intravenously every 2 weeks) at the National Hospital Organization Kinki-chuo Chest Medical Center (Osaka, Japan), Osaka International Cancer Institute (Osaka, Japan), and Osaka Habikino Medical Center (Osaka, Japan) between December 2015 (the date nivolumab was approved in Japan) and July 2016. This study was registered with the University Hospital Medical Information Network Clinical Trials Registry in Japan (UMIN000025908).

Data collection and evaluation. Clinical data, including age, sex, Eastern Cooperative Oncology Group performance status, smoking status, histological type, baseline C-reactive protein and 


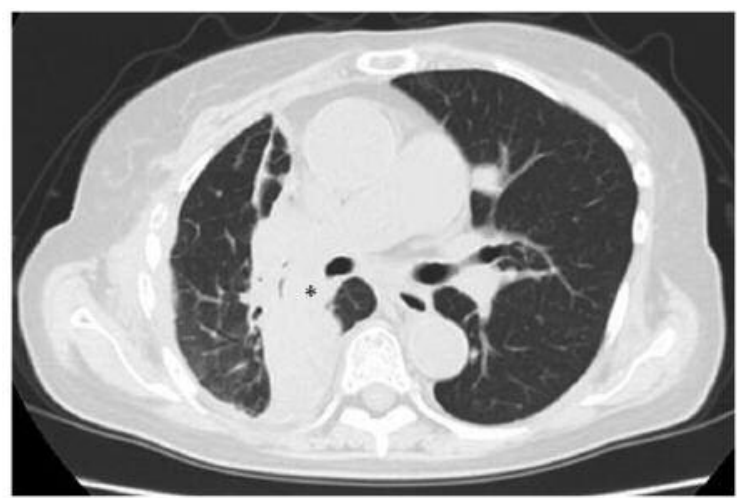

Figure 1. Representative imaging findings of airway obstruction adjacent to lung tumors. The lung tumor is indicated by asterisks.

lactate dehydrogenase concentrations (defined as those within 2 weeks prior to nivolumab treatment), the presence of pleural effusion and pulmonary metastasis, a history of radiation pneumonitis, and imaging findings of airway obstruction adjacent to lung tumors (IAOT) (Figure 1) at the time of commencing treatment with nivolumab, were collected from patient medical records. Data were also collected on the incidence of nivolumabrelated ILD and the grade of ILD. Associations between the incidence of ILD and patient characteristics were evaluated. Progression-free survival (PFS) was analyzed according to the presence or absence of IAOT. Clinical responses were defined according to the Response Evaluation Criteria in Solid Tumors (version 1.1) (9). PFS was defined as the duration between commencing treatment with nivolumab and disease progression or death from any cause. The patients were followed-up until March 31, 2017.

Statistical analyses. Multivariate analysis was performed using logistic regression. Survival curves were estimated using the Kaplan-Meier method and differences between the groups were analyzed using the log-rank test. All statistical analyses were conducted using JMP statistical software for Windows (version 13.0; SAS Institute Inc., Cary, NC, USA). A value of $p<0.05$ was considered statistically significant.

\section{Results}

Patient characteristics. A total of 201 patients with advanced non-small cell lung cancer were treated with nivolumab between December 17, 2015 and July 31, 2016. The patient characteristics are summarized in Table I. The median age was 68 (range $=27-87$ ) years. Most patients were male $(67.2 \%)$, and most had a history of smoking $(78.1 \%)$, and an Eastern Cooperative Oncology Group performance status of $0-1(76.1 \%)$. At the time of commencing treatment with nivolumab, 34 patients $(16.9 \%)$ had a history of radiation pneumonitis and 16 patients $(8.0 \%)$ had IAOT.
Table I. Patient characteristics $(n=201)$.

\begin{tabular}{|c|c|}
\hline Characteristic & Value \\
\hline \multicolumn{2}{|l|}{ Age (years } \\
\hline Median (range) & $68(27-87)$ \\
\hline \multicolumn{2}{|l|}{ Gender, n (\%) } \\
\hline Male & $135(67.2)$ \\
\hline Female & $66(32.8)$ \\
\hline \multicolumn{2}{|l|}{ Smoking status, $\mathrm{n}(\%)$} \\
\hline Current/ex-smoker & $157(78.1)$ \\
\hline Non-smoker & $44(21.9)$ \\
\hline \multicolumn{2}{|l|}{ Histology, n (\%) } \\
\hline Non-squamous & $159(79.1)$ \\
\hline Squamous & $42(20.9)$ \\
\hline \multicolumn{2}{|l|}{ ECOG PS, n (\%) } \\
\hline $0-1$ & $153(76.1)$ \\
\hline$\geq 2$ & $48(23.9)$ \\
\hline \multicolumn{2}{|l|}{$\mathrm{LDH}>240 \mathrm{IU} / 1, \mathrm{n}(\%)$} \\
\hline Yes & $77(38.3)$ \\
\hline No & $124(61.7)$ \\
\hline \multicolumn{2}{|l|}{$\mathrm{CRP}>0.3 \mathrm{mg} / \mathrm{dl}, \mathrm{n}(\%)$} \\
\hline Yes & $132(65.7)$ \\
\hline No & $69(34.3)$ \\
\hline \multicolumn{2}{|l|}{ PE, n (\%) } \\
\hline Yes & $89(44.3)$ \\
\hline No & $112(55.7)$ \\
\hline \multicolumn{2}{|c|}{ Pulmonary metastasis, $\mathrm{n}(\%)$} \\
\hline Yes & $115(57.2)$ \\
\hline No & $86(42.8)$ \\
\hline \multicolumn{2}{|c|}{ History of radiation pneumonitis, $\mathrm{n}(\%)$} \\
\hline Yes & $34(16.9)$ \\
\hline No & $167(83.1)$ \\
\hline \multicolumn{2}{|l|}{ IAOT, n (\%) } \\
\hline Yes & $16(8.0)$ \\
\hline No & $185(92.0)$ \\
\hline
\end{tabular}

CRP, C-Reactive protein; ECOG, Eastern Cooperative Oncology Group; IAOT, imaging findings of airway obstruction adjacent to lung tumors; LDH, lactate dehydrogenase; PE, pleural effusion; PS, performance status.

Multivariate analysis. In the multivariate analysis, a history of radiation pneumonitis and IAOT were associated with increased ILD risk, with odds ratios of $3.96(\mathrm{p}=0.012)$ and $6.59(p<0.004)$, respectively (Table II). In contrast, other factors were not associated with the incidence of ILD.

Grade of ILD. ILD occurred in six (37.5\%) out of 16 patients with IAOT and $19(10.3 \%)$ out of 185 patients without IAOT. Three out of the six patients with both ILD and IAOT had ILD of grade 4 or more. Conversely, only two $(10.5 \%)$ out of the 19 patients with ILD without IAOT had ILD of grade 4 or more (Table III).

Progression-free survival. The median PFS of patients with and without IAOT was 0.9 and 3.2 months, respectively $(p<0.001$; Figure 2). 
Table II. Multivariate odds ratios (ORs) for interstitial lung disease.

\begin{tabular}{lccc}
\hline Factor & Comparison & OR $(95.0 \% \mathrm{CI})$ & $p$-Value \\
\hline Gender & Male $v$ s. female & $1.98(0.55-7.07)$ & 0.296 \\
Smoking status & Current/ex-smoker $v s$. non-smoker & $1.24(0.27-5.69)$ & 0.778 \\
Histology & Squamous $v$ s. non-squamous & $1.28(0.44-3.78)$ & 0.648 \\
ECOG PS & $\geq 2 v s .<2$ & $0.63(0.18-2.21)$ & 0.471 \\
LDH & $>240 v s . \leq 240$ IU/l & $2.10(0.81-5.38)$ & 0.126 \\
CRP & $>0.3 v s . \leq 0.3 \mathrm{mg} / \mathrm{dl}$ & $0.95(0.30-2.95)$ & 0.925 \\
PE & Yes $v s$. no & $0.77(0.30-1.98)$ & 0.587 \\
Pulmonary metastasis & Yes $v s$. no & $0.89(0.33-2.41)$ & 0.821 \\
History of radiation pneumonitis & Yes $v s$. no & $3.96(1.35-11.60)$ & 0.012 \\
IAOT & Yes $v s$. no & $6.59(1.82-23.90)$ & 0.004 \\
\hline
\end{tabular}

CI, Confidence interval; CRP, C-reactive protein; ECOG, Eastern Cooperative Oncology Group; IAOT, imaging findings of airway obstruction adjacent to lung tumors; LDH, lactate dehydrogenase; PE, pleural effusion; PS, performance status.

Table III. Grade of experienced Interstitial lung disease (ILD) grade.

\begin{tabular}{lcccccc}
\hline IAOT & \multicolumn{7}{c}{ ILD grade } \\
\cline { 2 - 7 } & 1 & 2 & 3 & 4 & 5 & Total \\
\hline Yes $(\mathrm{n}=16 ; 8.0 \%)$ & 2 & 1 & 0 & 1 & 2 & 6 \\
No $(\mathrm{n}=185 ; 92.0 \%)$ & 9 & 6 & 2 & 1 & 1 & 19 \\
\hline
\end{tabular}

IAOT, Imaging findings of airway obstruction adjacent to lung tumors.

\section{Discussion}

In our study, a history of radiation pneumonitis and the presence of IAOT were associated with a significantly increased risk of developing ILD. Although in a previous study, a history of radiation pneumonitis was considered a risk factor for ILD (10), in our study, IAOT exhibited a higher odds ratio for ILD than the history of radiation pneumonitis.

PFS was also significantly shorter in patients with IAOT than in those without. There have been reports that showed that patients who develop immune-related adverse events, such as ILD, tended to have better outcomes $(11,12)$. However, in our study, patients with ILD and IAOT tended to exhibit earlier disease progression or death. Furthermore, ILD grade in patients with IAOT was more severe than in those without IAOT. These findings suggest that in terms of the developmental mechanism, ILD with IAOT differs from that without IAOT in patients treated with ICIs.

The PD1-PD-L1 pathway functions not only in antitumor immunity, but also in various immune environments, such as infection, and plays a critical role in negative feedback mechanisms that attenuate immune cell function (13-16).

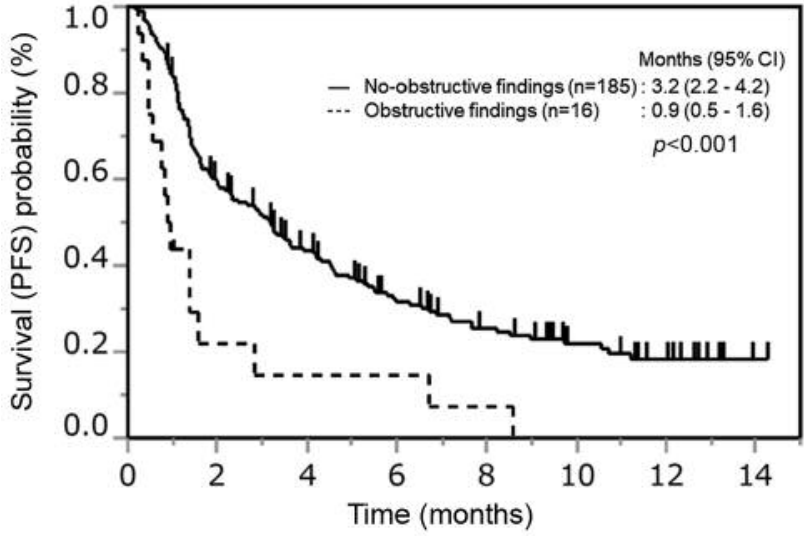

Figure 2. Kaplan-Meier curves for progression-free survival (PFS) according to imaging findings of airway obstruction adjacent to lung tumors. CI: Confidence interval.

It is common for patients with airway obstruction to develop recurrent obstructive pneumonitis. Therefore, we postulate that airway obstruction may be a source of active inflammation, and in such a lung microenvironment with inflammation, ICIs might induce excessive reactions that lead to severe ILD. Since it is difficult to know whether there is active inflammation or not, we used the term 'IAOT' rather than 'obstructive pneumonia'. Conversely, other factors that can be associated with the lung microenvironment (e.g. pulmonary metastasis and pleural effusion) did not correlate with the incidence of ILD in our multivariate analysis.

Our study has several important limitations. Firstly, the retrospective design means there is the potential for bias and confounding factors. We attempted to address this by building multivariate models and adjusting for confounding 
factors. Secondly, the number of patients with IAOT was relatively small. However, we were able to demonstrate significant findings from the multivariate analysis despite the small sample size. Finally, the judgment as to whether or not the patients had IAOT was entirely dependent on individual investigators.

In conclusion, a history of radiation pneumonitis and the presence of IAOT were significant risk factors for ILD in multivariate analysis. We suggest that clinicians should be careful in administration of ICIs if patients have IAOT. Further larger prospective studies are needed to determine the association between IAOT and ILD, not only in patients treated with nivolumab, but also patients treated with other ICIs.

\section{Conflicts of Interest}

Dr. Y. Taniguchi, Dr. A. Tamiya, Dr. S. Isa, Dr. K. Nakahama, Dr. T. Shiroyama, Dr. H. Suzuki, Dr. T. Inoue, Dr. M. Tamiya, Dr. T. Hirashima, Dr. F. Imamura, and Dr. S. Atagi report grants from Ono Pharmaceutical and Bristol-Myers Squibb. Dr. Y. Taniguchi, Dr. A. Tamiya, Dr. T. Shiroyama, Dr. H. Suzuki, Dr. M. Tamiya, Dr. T. Hirashima, Dr. F. Imamura, and Dr. S. Atagi report personal fees from Ono Pharmaceutical. Dr. Y. Taniguchi, Dr. A. Tamiya, Dr. M. Tamiya, Dr. T. Hirashima, Dr. F. Imamura, and Dr. S. Atagi report personal fees from Bristol-Myers Squibb during the conduct of the study.

\section{Acknowledgements}

The Authors wish to thank all of the patients who participated in this study and to thank Editage (www.editage.jp) for English language editing.

This study was supported by Ono Pharmaceutical Co., Ltd. and Bristol-Myers Squibb Co., Ltd.

\section{References}

1 Rittmeyer A, Barlesi F, Waterkamp D, Park K, Ciardiello F, von Pawel J, Gadgeel SM, Hida T, Kowalski DM, Dols MC, Cortinovis DL, Leach J, Polikoff J, Barrios C, Kabbinavar F, Frontera OA, De Marinis F, Turna H, Lee JS, Ballinger M, Kowanetz M, He P, Chen DS, Sandler A and Gandara DR: Atezolizumab versus docetaxel in patients with previously treated non-small-cell lung cancer (OAK): A phase 3, open-label, multicentre randomised controlled trial. Lancet 389(10066): 255-265, 2017.

2 Borghaei H, Paz-Ares L, Horn L, Spigel DR, Steins M, Ready NE, Chow LQ, Vokes EE, Felip E, Holgado E, Barlesi F, Kohlhaufl M, Arrieta O, Burgio MA, Fayette J, Lena H, Poddubskaya E, Gerber DE, Gettinger SN, Rudin CM, Rizvi N, Crino L, Blumenschein GR Jr., Antonia SJ, Dorange C, Harbison CT, Graf Finckenstein F and Brahmer JR: Nivolumab versus docetaxel in advanced nonsquamous non-small-cell lung cancer. N Engl J Med 373(17): 1627-1639, 2015.

3 Brahmer J, Reckamp KL, Baas P, Crino L, Eberhardt WE, Poddubskaya E, Antonia S, Pluzanski A, Vokes EE, Holgado E, Waterhouse D, Ready N, Gainor J, Aren Frontera O, Havel L,
Steins M, Garassino MC, Aerts JG, Domine M, Paz-Ares L, Reck M, Baudelet C, Harbison CT, Lestini B and Spigel DR: Nivolumab versus docetaxel in advanced squamous-cell nonsmall-cell lung cancer. N Engl J Med 373(2): 123-135, 2015.

4 Herbst RS, Baas P, Kim D-W, Felip E, Pérez-Gracia JL, Han JY, Molina J, Kim J-H, Arvis CD, Ahn M-J, Majem M, Fidler MJ, de Castro G, Garrido M, Lubiniecki GM, Shentu Y, Im E, Dolled-Filhart $\mathrm{M}$ and Garon $\mathrm{EB}$ : Pembrolizumab versus docetaxel for previously treated, pd-11-positive, advanced nonsmall-cell lung cancer (Keynote-010): A randomised controlled trial. The Lancet 387(10027): 1540-1550, 2016.

5 Reck M, Rodriguez-Abreu D, Robinson AG, Hui R, Csoszi T, Fulop A, Gottfried M, Peled N, Tafreshi A, Cuffe S, O'Brien M, Rao S, Hotta K, Leiby MA, Lubiniecki GM, Shentu Y, Rangwala $\mathrm{R}$ and Brahmer JR: Pembrolizumab versus chemotherapy for PD-L1-positive non-small-cell lung cancer. N Engl J Med 375(19): 1823-1833, 2016.

6 Brahmer JR, Rodriguez-Abreu D, Robinson AG, Hui R, Csõszi T, Fülöp A, Gottfried M, Peled N, Tafreshi A, Cuffe S, O'Brien M, Rao S, Hotta K, Leiby MA, McLean J, Shentu Y, Rangwala RA and Reck M: Progression after the next line of therapy (PFS2) and updated os among patients (pts) with advanced NSCLC and PDL1 tumor proportion score (TPS) $\geq 50 \%$ enrolled in keynote- 024 . J Clin Oncol 35(15_suppl): 9000-9000, 2017.

7 Gettinger SN, Horn L, Gandhi L, Spigel DR, Antonia SJ, Rizvi NA, Powderly JD, Heist RS, Carvajal RD, Jackman DM, Sequist LV, Smith DC, Leming P, Carbone DP, Pinder-Schenck MC, Topalian SL, Hodi FS, Sosman JA, Sznol M, McDermott DF, Pardoll DM, Sankar V, Ahlers CM, Salvati M, Wigginton JM, Hellmann MD, Kollia GD, Gupta AK and Brahmer JR: Overall survival and long-term safety of nivolumab (anti-programmed death 1 antibody, BMS-936558, ONO-4538) in patients with previously treated advanced non-small-cell lung cancer. J Clin Oncol 33(18): 2004-2012, 2015.

8 Topalian SL, Hodi FS, Brahmer JR, Gettinger SN, Smith DC, McDermott DF, Powderly JD, Carvajal RD, Sosman JA, Atkins MB, Leming PD, Spigel DR, Antonia SJ, Horn L, Drake CG, Pardoll DM, Chen L, Sharfman WH, Anders RA, Taube JM, McMiller TL, Xu H, Korman AJ, Jure-Kunkel M, Agrawal S, McDonald D, Kollia GD, Gupta A, Wigginton JM and Sznol M: Safety, activity, and immune correlates of anti-PD-1 antibody in cancer. N Engl J Med 366(26): 2443-2454, 2012.

9 Eisenhauer EA, Therasse P, Bogaerts J, Schwartz LH, Sargent D, Ford R, Dancey J, Arbuck S, Gwyther S, Mooney M, Rubinstein L, Shankar L, Dodd L, Kaplan R, Lacombe D and Verweij J: New response evaluation criteria in solid tumours: Revised RECIST guideline (version 1.1). Eur J Cancer 45(2): 228-247, 2009.

10 Tamiya A, Tamiya M, Nakahama K, Taniguchi Y, Shiroyama T, Isa SI, Inoue T, Okishio K, Nishino K, Kumagai T, Suzuki H, Hirashima T, Imamura F and Atagi S: Correlation of radiation pneumonitis history before nivolumab with onset of interstitial lung disease and progression-free survival of patients with pretreated advanced non-small cell lung cancer. Anticancer Res 37(9): 5199-5205, 2017.

11 Haratani K, Hayashi H, Chiba Y, Kudo K, Yonesaka K, Kato R, Kaneda H, Hasegawa Y, Tanaka K, Takeda M and Nakagawa K: Association of immune-related adverse events with nivolumab efficacy in non-small-cell lung cancer. JAMA Oncol 4(3): 374378, 2017. 
12 Sato K, Akamatsu H, Murakami E, Sasaki S, Kanai K, Hayata A, Tokudome N, Akamatsu K, Koh Y, Ueda H, Nakanishi M and Yamamoto N: Correlation between immune-related adverse events and efficacy in non-small cell lung cancer treated with nivolumab. Lung Cancer 115: 71-74, 2018.

13 Zelinskyy G, Myers L, Dietze KK, Gibbert K, Roggendorf M, Liu J, Lu M, Kraft AR, Teichgraber V, Hasenkrug KJ and Dittmer U: Virus-specific CD8+ T-cells upregulate programmed death-1 expression during acute friend retrovirus infection but are highly cytotoxic and control virus replication. J Immunol 187(7): 3730-3737, 2011.

14 Hofmeyer KA, Jeon H and Zang X: The PD-1/PD-L1 (B7-H1) pathway in chronic infection-induced cytotoxic t lymphocyte exhaustion. J Biomed Biotechnol 2011: 451694, 2011.
15 Yao S, Wang S, Zhu Y, Luo L, Zhu G, Flies S, Xu H, Ruff W, Broadwater M, Choi IH, Tamada K and Chen L: PD-1 on dendritic cells impedes innate immunity against bacterial infection. Blood 113(23): 5811-5818, 2009.

16 Brown KE, Freeman GJ, Wherry EJ and Sharpe AH: Role of PD-1 in regulating acute infections. Curr Opin Immunol 22(3): $397-401,2010$

Received March 27, 2018

Revised April 28, 2018

Accepted May 2, 2018 